\title{
Production of Bio-Fungicide from Sugarcane Bagasse using Pichia membranifaciens Yeast and its Activity Against Post-Harvest Pathogenic Fungi
}

\author{
Fereshteh Ahmadi ${ }^{1}$, Ghasem D. Najafpour ${ }^{1, *(\mathbb{D})}$, Maedeh Mohammadi ${ }^{1(D)}$ \\ 1 Biotechnology Research Laboratory, Faculty of Chemical Engineering, Noshirvani University of Technology, Babol, Iran; \\ fereshtehahmadi1989@yahoo.com (F.A.); najafpour@nit.ac.ir (G.D.N.); m.mohammadi@nit.ac.ir (M.M.); \\ * Correspondence: najafpour@nit.ac.ir;
}

Scopus Author ID 55485049700

Received: 30.09.2020; Revised: 22.10.2020; Accepted: 23.10.2020; Published: 26.10.2020

\begin{abstract}
Antagonistic yeast Pichia membranifaciens can produce killer toxins and hydrolytic enzymes to degrade pathogenic fungi cell walls. In this study, sugarcane bagasse was hydrolyzed and used as a low-cost carbon source to produce bio-fungicide using $P$. membranifaciens. In a growth medium obtained from bagasse hydrolysis containing $25 \mathrm{~g} / \mathrm{l}$ sugar, with optimized amounts of nitrogen sources $(2 \%(\mathrm{w} / \mathrm{v})), \mathrm{NaCl}$ and $\mathrm{K}_{2} \mathrm{HPO}_{4}(0.5 \%(\mathrm{w} / \mathrm{v}))$ and in the presence of hydrophilic surfactant, Triton X100 $(0.02 \%(\mathrm{w} / \mathrm{v}))$, the yeast was able to produce $3782 \mathrm{mg} / \mathrm{l}$ bio-fungicide. The activity and toxicity of the produced bio-fungicide were tested against some post-harvest pathogenic fungi, including Aspergillus niger, Penicillium digitatum, and Phytophthora capsici. Minimum biocidal concentration (MBC) and minimum inhibitory concentration (MIC) were determined to be 378.2 and $37.82 \mathrm{mg} / \mathrm{l}$, respectively. According to the results, the produced bio-fungicide has the potential for preserving agricultural products in the warehouse.
\end{abstract}

Keywords: antagonistic yeast; Pichia membranifaciens; post-harvest pathogens; Aspergillus niger; bio-fungicide.

(C) 2020 by the authors. This article is an open-access article distributed under the terms and conditions of the Creative Commons Attribution (CC BY) license (https://creativecommons.org/licenses/by/4.0/).

\section{Introduction}

Filamentous fungi that produce mycotoxin can cause plant diseases, reduce the quality and yield of crops, and in addition to economic damage, pose risks for human and animal health. Although the estimation of post-harvest mortality, particularly through fungal diseases, is not precise, some data indicate that, on average, about $30 \%$ of crops destroy between production and consumption [1]. Post-harvest diseases might be controlled through the treatment of fruits and crops with synthetic chemical fungicides [2]. However, with the demand for pesticide-free fruits and vegetables, and according to the new regulations, the use of chemical pesticides should be reduced [3].

Biological control of agricultural pests by antagonistic yeasts has attracted considerable attention as a promising alternative for chemical pesticides with less environmental impact, which can be used alone or as part of pest management practices to reduce the use of synthetic fungicides [4]. Antagonistic yeasts are of significant importance for pathologists due to their ability to produce extracellular secondary metabolites [5]. These secondary metabolites that are made up of protein adversely affect pathogenic fungi and can kill them. The toxicity of 
these proteins depends on their ability to enter the fungi cells [6]. Several antagonistic yeasts can produce such toxins, called killer phenotypes, among them are Pichia sp. [7, 8].

In 1992, Marquin et al. [9] found that P. membranifaciens, which was isolated from olive brine, had a wide range of killer toxin activity. It can produce two types of toxin (PMKT and PMKT2 [10]), which affect the cell wall of pathogenic fungi. PMKT has an affinity to (1, 6) -d- $\beta$-glucan, while PMKT2 is absorbed by cell wall proteins [11]. Later, Masih et al. [12] simultaneously cultivated $P$. membranifaciens and pathogenic fungus Botrytis cinerea on a plate, where $P$. membranifaciens could suppress the grey mold disease by destroying the cell wall of $B$. cinerea and causing its cytoplasm leakage. Santos et al. [13] isolated 42 species of Pichia sp. from 20 different sources and tested them against 18 strains of pathogenic $B$. cinerea. Results showed that $P$. membranifaciens and $P$. anamola showed the highest inhibition against B. cinerea.

In addition to the production of killer toxin against pathogenic fungi, $P$. membranifaciens produces hydrolyzing enzymes including exochitinase, endochitinase, and $\beta$ 1,3-glucanase [14], and antifungal volatile organic compounds such as 2-nonanone, 2phenethyl alcohol, 1,3,5,7-cyclooctatetraene and 3-methyl-1-butanol, which cause the death of pathogenic fungi $[15,16]$. Cao et al. investigated the synergistic effects of $P$. membranifaciens and other controllers such as $\mathrm{CaCl}_{2}$ [17] and methyl-jasmonate [18] to control Colletotrichum acutatum, and ammonium molybdate [19], and BTH (benzothiadiazole-7-carboxylic acid-smethyl ester) [20] to control Penicillium expansum. Their results showed that simultaneous treatment led to better control of post-harvest decay due to the increased activity of the enzymes. Zhang et al. [21] assessed the inhibition of P. membranifaciens against Monilinia fructicola, and a $76 \%$ reduction in the decaying rate was shown in vivo. Since $P$. membranifaciens is usually used as an antagonist agent for control of post-harvest pathogens during the cold storage of fruits [22], for practical purposes, it is important to develop formulations of it which could be easily used at a large scale. In this regard, Zhang et al. [23] compared the biocontrol efficacy of vacuum-dried and fresh $P$. membranifaciens on citrus fruit and demonstrated that no significant difference in the biocontrol effects of fresh and active dried yeast was observed.

Despite all efforts, problems such as high production costs hinder the commercialization of bio-fungicides [24]. With the aim of reducing the production cost of biofungicides, sugarcane bagasse was used as an inexpensive substrate in this study to produce bio-fungicide using $P$. membranifaciens. The killer activity of the produced bio-fungicide against some post-harvest pathogenic fungi, including $P$. digitatum, A. niger, and $P$. capsici was investigated.

\section{Materials and Methods}

\subsection{Yeast and pathogenic fungi.}

The yeast Pichia membranifaciens IBRC-M 30146 was purchased from the National Iranian Biological Resource Center (IBRC), then cultivated in a standard YMB medium containing $0.3 \%(\mathrm{w} / \mathrm{v})$ yeast extract (Himedia, Iran), $0.3 \%(\mathrm{w} / \mathrm{v})$ malt extract (Merck, Germany), $0.5 \%$ (w/v) peptone (Himedia, Iran) and 1\% (w/v) glucose (Merck, Germany) at 25 ${ }^{\circ} \mathrm{C}$ and $\mathrm{pH} 6.8$.

Pathogenic fungi on which the killer activity of the produced bio-fungicide was tested were provided from Partonar Company, Alborz, Iran. For this purpose Aspergillus niger causes 
black mold disease of grains and fruits, Penicillium digitatum causing green mold disease of citrus [25], and Phytophthora capsici that causes mold disease of Cucurbitaceae family were used.

\subsection{Sugarcane bagasse.}

Sugarcane bagasse was provided from a local market, Mazandaran, Iran. It was crushed, dried, and then characterized to determine its total sugar, glucose, and protein content. The bagasse was then hydrolyzed by dilute $\mathrm{H}_{2} \mathrm{SO}_{4}(0.25 \%$ v/v) [26], and the obtained hydrolysate was used as a sugar source for the cultivation of the yeast. The total sugar content was determined by the phenol sulfuric acid method [27], the glucose content of the hydrolysate was determined by the dinitrosalicylic acid (DNS) method [28], and the amount of protein was estimated by the Bradford method [29] using standard bovine serum albumin (EquiTech-Bio, America).

\subsection{Medium optimization.}

In addition to a carbon source, microorganisms require different nutrients to grow and reproduce. In this regard, the effects of various nitrogen sources (urea, yeast extract, malt extract, peptone, ammonium chloride $\left(\mathrm{NH}_{4} \mathrm{Cl}_{2}\right)$ and ammonium sulfate $\left.\left(\left(\mathrm{NH}_{4}\right)_{2} \mathrm{SO}_{4}\right)\right)$, mineral salts $\left(\mathrm{NaCl}, \mathrm{CaCl}_{2}, \mathrm{MgCl}_{2}, \mathrm{MgSO}_{4}, \mathrm{FeSO}_{4}, \mathrm{KH}_{2} \mathrm{PO}_{4}\right.$, and $\left.\mathrm{K}_{2} \mathrm{HPO}_{4}\right)$ and hydrophilic surfactants (Triton X-100 and Tween 80) on product formation were investigated, and if they had a positive efficacy on production, their optimal value was determined using the one-factor-at-a-time approach. Since protein (bio-fungicide) production is mostly affected by nitrogen source, at first, different nitrogen sources $(1 \%(\mathrm{w} / \mathrm{v}))$ were tested in the medium obtained from bagasse hydrolysis. Afterward, the nitrogen source with the highest effect on bio-fungicide production was selected, and its concentration was optimized in the range of 1 to $9 \%(w / v)$. In the next step, the influence of the surfactant on the protein production was studied in the range of 0.01 to $0.04 \%(\mathrm{w} / \mathrm{v})$, and the optimum amount of the preferred surfactant was determined. Then, the impact of mineral salts $(0.1(\mathrm{w} / \mathrm{v}))$ on the bio-fungicide production was investigated, and the optimum concentration of the selected salts was determined.

\subsection{Bio-fungicide production.}

P. membranifaciens $(3 \% \mathrm{v} / \mathrm{v})$ were inoculated into a hydrolysate medium containing nitrogen source, mineral salts, and surfactant and incubated at $25{ }^{\circ} \mathrm{C}$ and $\mathrm{pH}$ 6.8. In the course of fermentation, cell dry weight (CDW), sugar consumption, and protein production were monitored. Bio-fungicide is an extracellular protein product that cells secrete it into the liquid medium. To measure the protein content, an aliquot of the culture was centrifuged at $6000 \mathrm{rpm}$ at $4{ }^{\circ} \mathrm{C}$ for $10 \mathrm{~min}$. Then, under a sterile condition, the supernatant was passed through a 0.45 $\mu \mathrm{m}$ syringe filter, and its protein content was measured following the Bradford method.

\subsection{Killer activity assay.}

Toxicity and activity of the bio-fungicide were investigated by disk diffusion and direct contact test. After separating the cells by centrifugation and filtering, the remaining filtrate, which contained bio-fungicide, was tested for killer activity.

To observe the effect of the bio-fungicide on the pathogenic fungi and their hyphae, pathogenic fungi were inoculated in $50 \mathrm{ml}$ media in two groups, one as control and the other 
as a test group, then incubated at $25{ }^{\circ} \mathrm{C}$ for $24 \mathrm{~h}$. Afterward, $30 \mathrm{ml}$ of the filtered bio-fungicide was added to the test group and incubated for another $24 \mathrm{~h}$. Next, the difference between the two groups was examined visually.

\subsubsection{Diffusion test.}

YMA medium was prepared in several Petri dishes. Then a $200 \mu \mathrm{l}$ of each pathogenic fungi suspension, which was grown on the YMB medium overnight, was inoculated on the Petri plates and spread uniformly over the agar medium. Then several wells with a diameter of $10 \mathrm{~mm}$ were created on the agar surface, and in each well, $100 \mu \mathrm{l}$ of filtrate with different concentrations of bio-fungicide was added. The plates were then incubated at $25^{\circ} \mathrm{C}$ for $24 \mathrm{~h}$. The created halos around each well was an indication of the activity and toxicity of the biofungicide [30].

\subsubsection{MIC and MBC assays.}

The fungicidal efficacy of the bio-fungicide was examined using the standard broth dilution method (CLSI-M07-A9-2012). The bio-fungicide was placed in direct contact with the pathogenic fungus in a liquid medium. The method was used to determine and measure the minimum inhibitory concentration (MIC) and minimum biocidal concentration (MBC), through the macro dilution method. The MIC and MBC were determined in YMB using serial dilutions of bio-fungicide in concentrations ranging from 3782 to $3782 \times 10^{-8} \mathrm{mg} / \mathrm{l}$ with adjusted fungus concentration 0.10 at $625 \mathrm{~nm}\left(1 \times 10^{8} \mathrm{CFU} / \mathrm{ml}, 0.5 \mathrm{McFarland}\right.$ 's standard $)$ [31, 32]. The negative control used in this study contained YMB with tested fungus, and the positive control included YMB and the filtrate containing the bio-fungicide (1:1). The temperature and time of incubation were $25^{\circ} \mathrm{C}$ and $24 \mathrm{~h}$, respectively. After 24 to $48 \mathrm{~h}$ the liquid was cloudy in some test tubes. The MIC and MBC were noted by the turbidity of the test tubes before and after incubation. The growth ability of pathogenic fungi in each tube in the presence of different concentrations of the bio-fungicide was measured by optical density reading at $600 \mathrm{~nm}$ using a spectrophotometer. To check the toxin effect, the culture was centrifuged, and the residual sediment was washed several times with physiological serum, and then grown on YMA medium, and the growth of colonies was investigated. All tests were carried out in triplicate to ensure the accuracy of the results.

\section{Results and Discussion}

\subsection{Substrates and nutrients.}

Characterization of sugarcane bagasse indicated that it contained $75.3 \%$ total sugar and $7.1 \%$ protein. The sugarcane bagasse was subjected to dilute acid hydrolysis, and then the hydrolysate with glucose content of around $25 \mathrm{~g} / \mathrm{l}$ was used to grow the P. membranifaciens. Figure 1 shows the CDW, sugar consumption, and bio-fungicide (protein) production within $120 \mathrm{~h}$ fermentation. As can be seen in the figure, the medium obtained from the bagasse hydrolysis initially contained some protein $(1095 \mathrm{mg} / \mathrm{l})$ that was consumed by the microorganism, and its concentration dropped drastically within $18 \mathrm{~h}$ of fermentation. Then, the production of protein as the product commenced along with cell mass production and continued up to $86 \mathrm{~h}$ when the product concentration reached its maximum concentration of 
$1075 \mathrm{mg} / \mathrm{l}$. Thereafter, the microorganism began to consume the product due to the expiration of the sugar content in the culture, which resulted in a decrease in protein concentration.

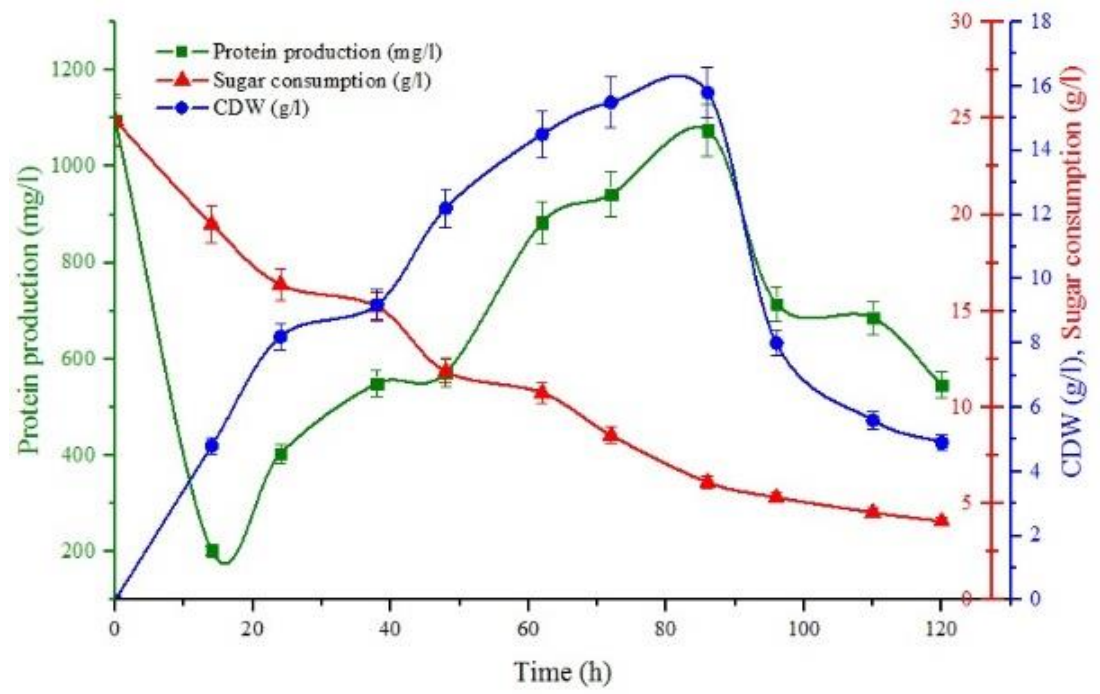

Figure 1. CDW, sugar consumption, and protein production by $P$. membranifaciens.

The production of bio-fungicide in the bagasse hydrolysate medium in the absence and presence of various nitrogen sources was investigated; the results are presented in Figure 2 A. Results showed that the cell metabolic pathway was strongly influenced by the nitrogen source. Urea and ammonium chloride caused severe alkalinity in the medium and needed to be neutralized with acid first. These nitrogen sources did not show any encouraging effect on biofungicide production; even in the presence of urea, the protein production reduced compared to the nitrogen-free medium. In the case of the other nitrogen sources, the addition of $1 \%(\mathrm{w} / \mathrm{v})$ of each nitrogen source to the bagasse hydrolysate was effective in enhancing the protein production compared to the control medium. The combination of three nitrogen sources, i.e., peptone, yeast extract, and malt extract (PYM), with the mass ratio (5:3:3), had the highest effect on the bio-fungicide production. In the presence of PYM as a nitrogen source $(1 \%(\mathrm{w} / \mathrm{v}))$, $2215 \mathrm{mg} / \mathrm{l}$ protein was synthesized by the cells, which was higher than that produced by individual nitrogen sources. Hence, the content of PYM in the medium was varied in the range of 1 to $9 \%(\mathrm{w} / \mathrm{v})$, and its effect on protein production was monitored (Figure $2 \mathrm{~B}$ ). The increase of the PYM from 1 to $2 \%(\mathrm{w} / \mathrm{v}$ ) considerably improved the concentration of the synthesized bio-fungicide from 2215 to $2900 \mathrm{mg} / \mathrm{l}$; however, further increase of the nitrogen source concentration in the medium was not effective to enhance the product formation.

The effect of two hydrophilic surfactants, Tween 80 and Triton X100, on product formation was investigated, as shown in Figure 2 C. Triton X100 was more effective than Tween 80 at the same concentration, and optimum surfactant concentration was determined to be $0.02 \%(\mathrm{w} / \mathrm{v})$. At this concentration of surfactants, the product formation was 3222 and 3429 $\mathrm{mg} / \mathrm{l}$ in the presence of Tween 80 and Triton X100, respectively. Surfactant helps to dissolve more oxygen in the liquid phase and hence provides better accessibility to oxygen for the aerobic yeast. Ions and salts also affect the metabolic activity of the cell; they act as the original regulator of the production enzymes and/or stimulants in the growth medium. On the other hand, some salts, especially at high concentrations, have inhibitory effects on the yeast. In this regard, the presence of several salts in the growth medium was individually examined to select the salts and ions that have a positive effect on bio-fungicide production. Figure $2 \mathrm{D}$ shows the effect of different salts and ions on bio-fungicide production. The medium containing $\mathrm{NaCl}$ 
and $\mathrm{K}_{2} \mathrm{HPO}_{4}$ revealed increased protein production; however, other minerals and salts such as $\mathrm{FeSO}_{4}, \mathrm{MgCl}_{2}, \mathrm{MgSO}_{4}, \mathrm{KH}_{2} \mathrm{PO}_{4}$, and $\mathrm{CaCl}_{2}$ had no or even negative effect on product formation. The optimal amounts of $\mathrm{NaCl}$ and $\mathrm{K}_{2} \mathrm{HPO}_{4}$ were determined as $0.5 \%$ (w/v) with product formation of 3518 and $3782 \mathrm{mg} / \mathrm{l}$, as exhibited in Figure $2 \mathrm{E}$ and F, respectively.
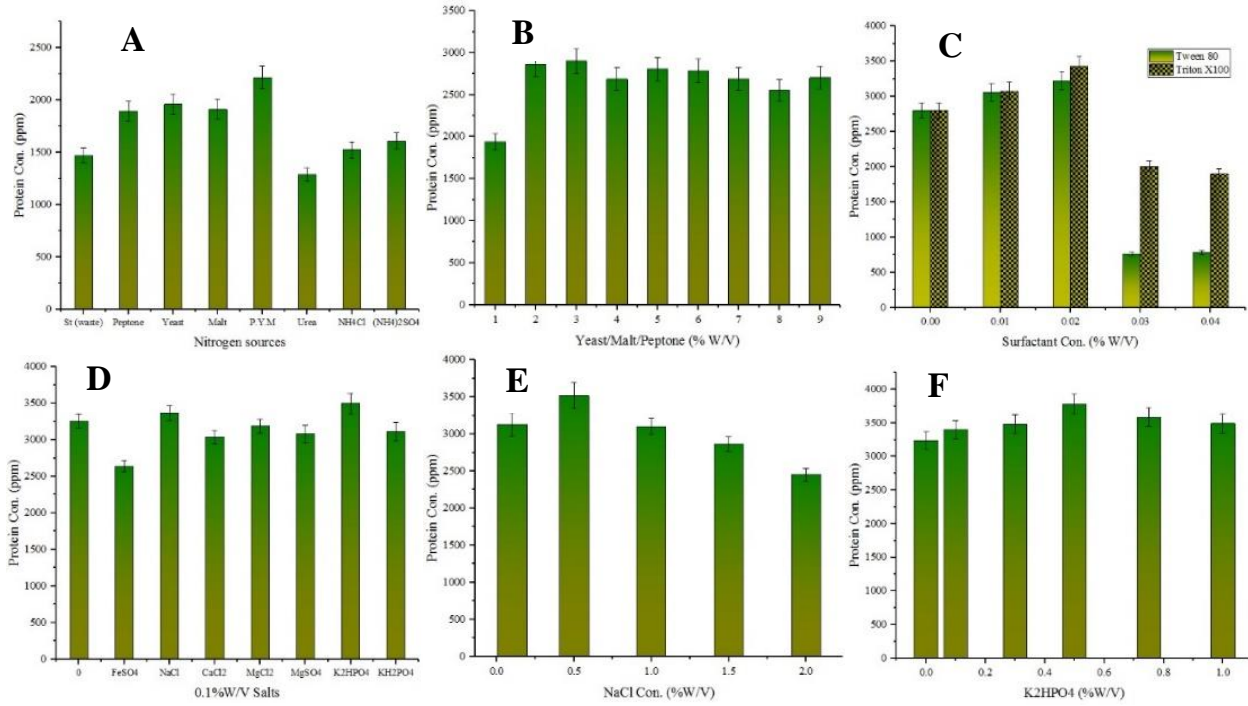

Figure 2. Optimization of nutrient sources for the bio-fungicide production: A) choice of nitrogen source, B) optimization of nitrogen source concentration, C) effect of surfactant and its concentration, D) effect of different salts, E) effect of $\mathrm{NaCl}$ concentration, and F) effect of $\mathrm{K}_{2} \mathrm{HPO}_{4}$ concentration.

\subsection{Killer toxin activity.}

\subsubsection{Diffusion test.}

The effect of bio-fungicide on the growth of pathogenic fungi is shown in Figure 3. After $24 \mathrm{~h}$, the growth of pathogenic microorganisms around the wells at the surface of the plate was prevented. On the plate containing $P$. digitatum, there was no trace of growth at high concentration, and the plate was completely clear. This indicates that the produced biofungicide had a greater killing effect on $P$. digitatum compared to other fungi.

The diameter of the halo around each well was measured, as shown in Table 1. The increase in the concentration of the bio-fungicide increased the diameter of the inhibition area. $P$. digitatum revealed a larger inhibition zone than other pathogenic fungi, and it was more affected by the bio-fungicide.

Table 1. Halo diameter around the wells affected by the bio-fungicide from $P$. membranifaciens.

\begin{tabular}{|c|c|c|c|c|c|}
\hline \multicolumn{2}{|r|}{ P. digitatum } & \multicolumn{2}{|r|}{ A. niger } & \multicolumn{2}{|r|}{ P. capsici } \\
\hline Label & Halo diameters (mm) & Label & Halo diameters (mm) & Label & Halo diameters (mm) \\
\hline $\mathbf{A}$ & 0 & $\mathrm{E}$ & 0 & I & 0 \\
\hline B & $3.9-12.9$ & $\mathrm{~F}$ & $1.3-3.9$ & $\mathrm{~J}$ & $0-9.0$ \\
\hline $\mathbf{C}$ & $12.9-38.7$ & $\mathrm{G}$ & $9.0-14.2$ & $\mathrm{~K}$ & $6.5-12.9$ \\
\hline D & 38.7 & $\mathrm{H}$ & $9.0-21.9$ & $\mathrm{~L}$ & $9.0-15.5$ \\
\hline
\end{tabular}

\subsubsection{MIC and MBC determinations.}

As shown in Figure 4, in the test tube with the bio-fungicide concentration of $3782 \times 10^{-}$ ${ }^{1} \mathrm{mg} / \mathrm{l}$, no fungi growth was observed, and in the next tube, with a bio-fungicide concentration of $3782 \times 10^{-2} \mathrm{mg} / \mathrm{l}$, the growth was inhibited. Accordingly, the concentrations of $3782 \times 10^{-1}$ and $3782 \times 10^{-2} \mathrm{mg} / \mathrm{l}$ were determined as MBC and MIC, respectively. 


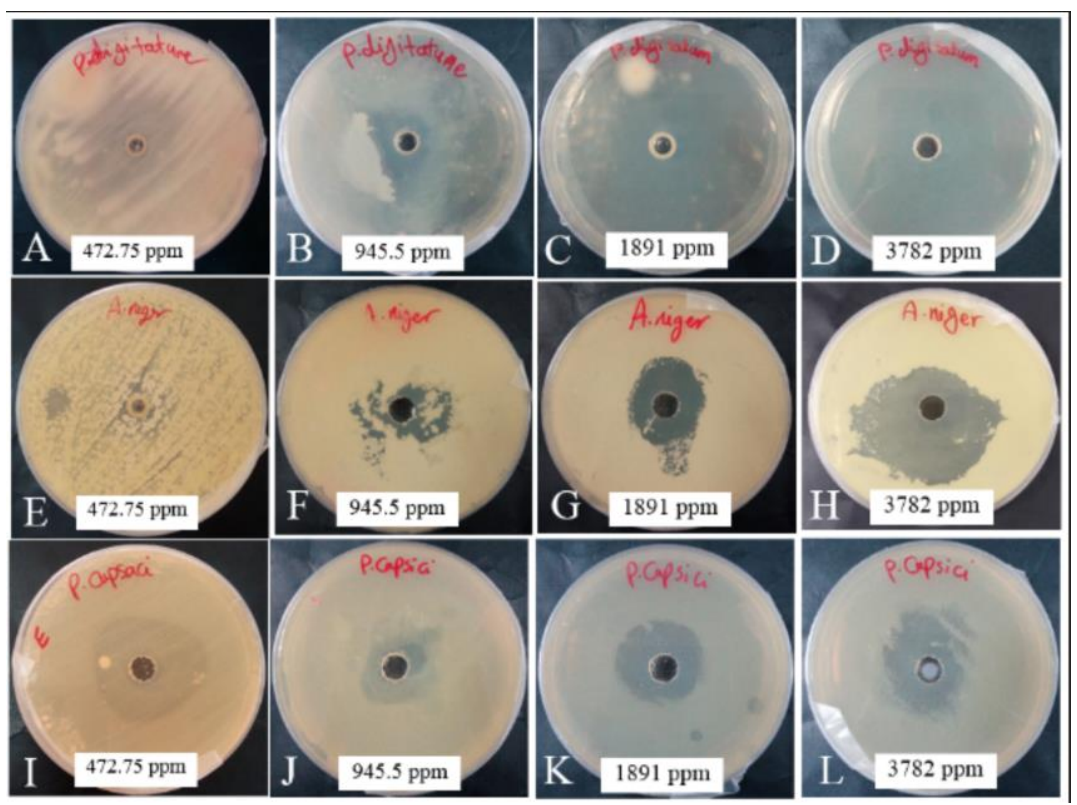

Figure 3. The inhibitory effect of the produced bio-fungicide at different concentrations on pathogenic fungi: (A-D) P. digitatum, (E-H) A. niger, and (I-L) P. capsici.
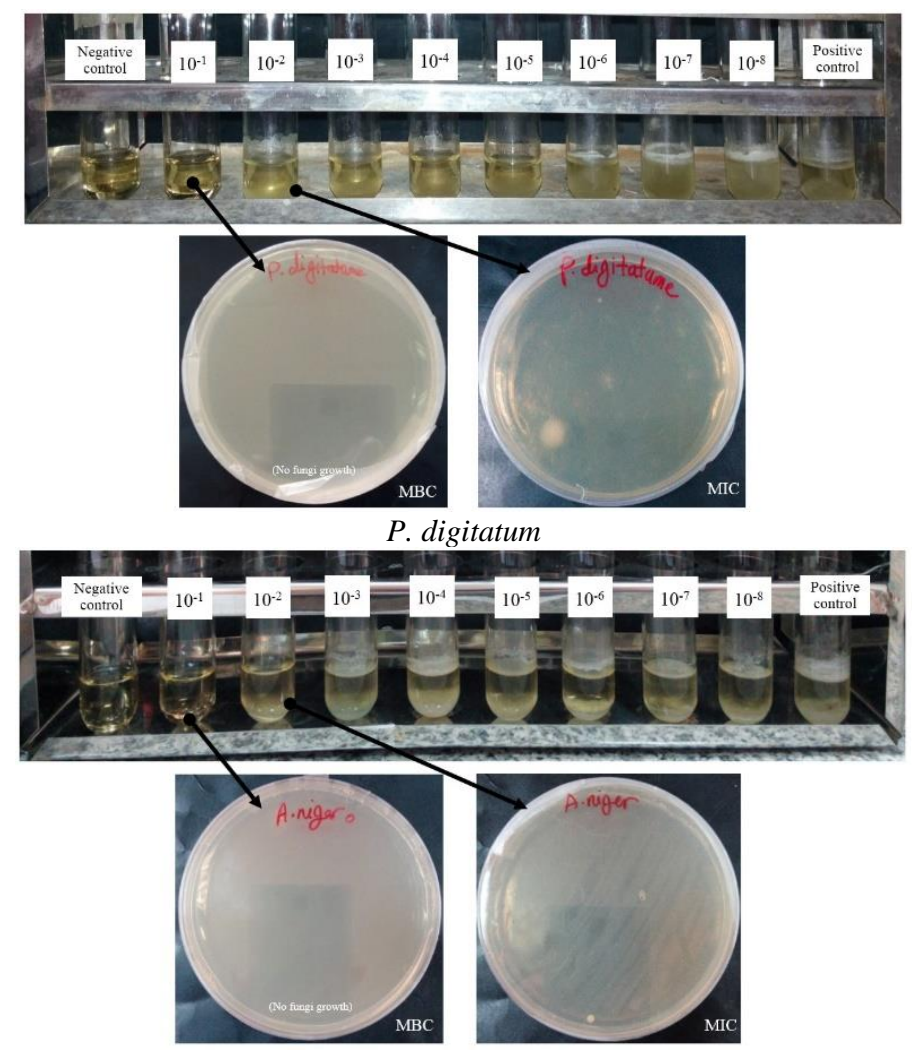

A. niger

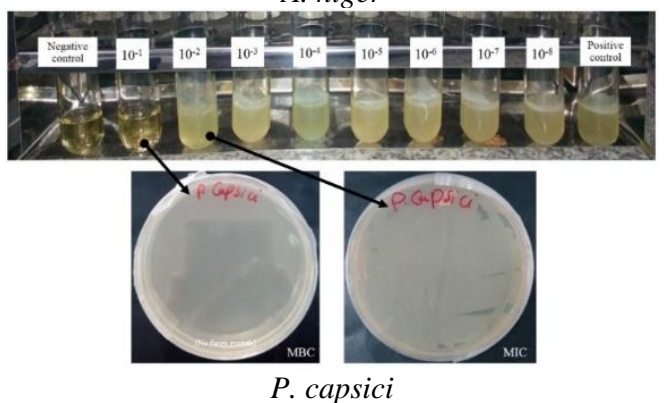

Figure 4. Determination of MIC and MBC for pathogenic fungi. 
Measuring the fungi cell growth in the liquid culture and their opacity was carried out to assess the killer activity of the produced bio-pesticide; the results are illustrated in Figure 5. Results indicated that the produced bio-fungicide was most effective on the growth of pathogenic fungus $P$. digitatum, followed by $A$. niger and $P$. capsici. In the tubes with the same concentrations of the bio-fungicide, the growth of $A$. niger and $P$. capsici was higher than $P$. digitatum, indicating that the pathogenic fungus $P$. digitatum was more susceptible to the biofungicide and its growth was more hindered in the presence of the toxin.

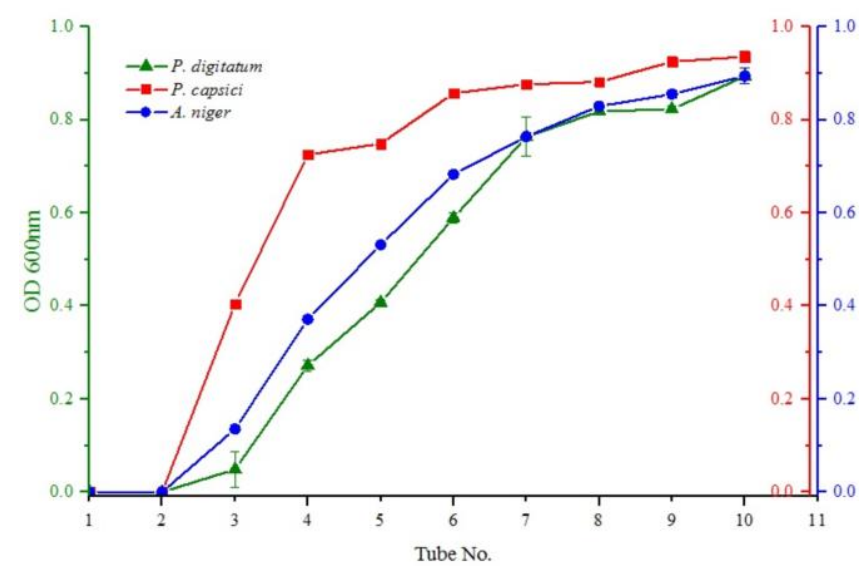

Figure 5. The growth ability of pathogenic fungi in cultures with different concentrations of bio-fungicide.

In the present study, when pathogenic fungi were grown on the YMB, and the biofungicide was added, the fungi failed to germinate, and their hyphae were destroyed, as depicted in Figure 6. As observed, in the bottle which contained the bio-fungicide, no growth of pathogenic fungi was observed, signifying the killer activity of the bio-fungicide. Table 2 presents a summary of the reports available in the literature on the inhibitory effect of $P$. membranifaciens on various pathogenic fungi. The focus of the current study was on the utilization of a low-cost substrate to reduce the production cost of bio-fungicide. Results of the current study indicated that the use of bagasse hydrolysate as the growth medium and optimization of the nutrients and element added to the medium resulted in the successful production of bio-fungicide, which could effectively inhibit the growth of some pathogenic fungi.

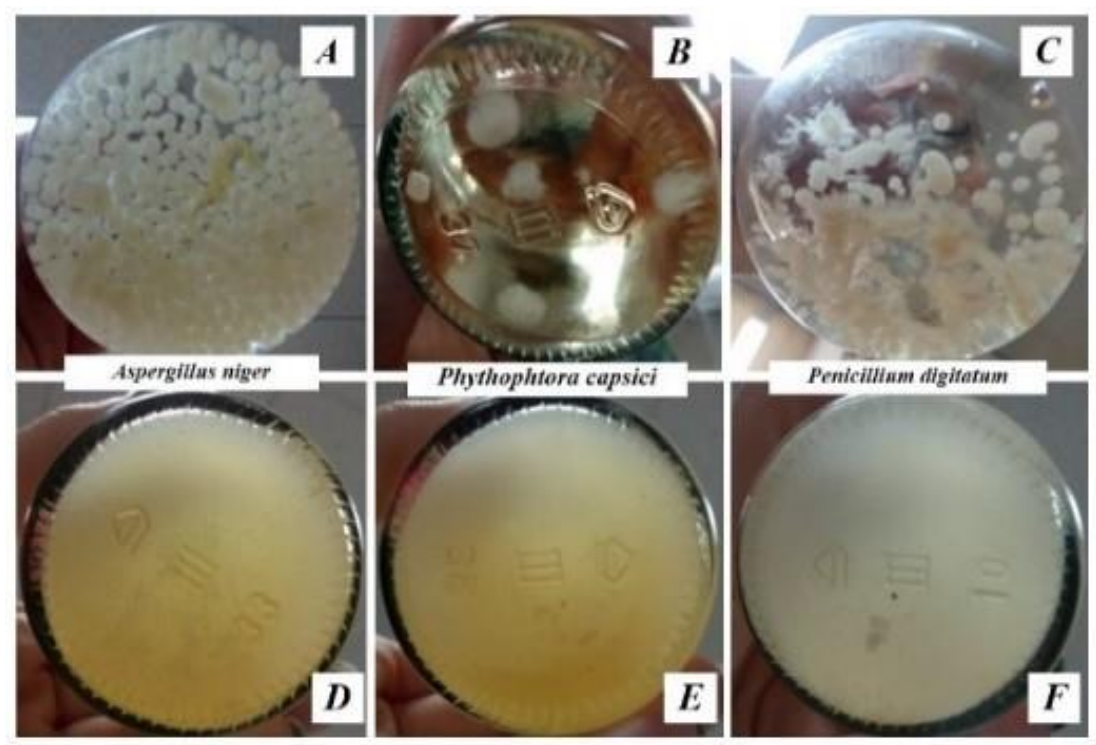

Figure 6. A-C) Control group: Growth of pathogenic fungi on YMB and D-F) Test group: destroyed hyphae of pathogenic fungi in the presence of $3782 \mathrm{mg} / \mathrm{l}$ of bio-fungicide in YMB. 
Table 2. Summary of studies on the inhibitory effect of $P$. membranifaciens on pathogenic fungi.

\begin{tabular}{|c|c|c|c|c|}
\hline $\begin{array}{l}\text { Pathogenic } \\
\text { microorganism }\end{array}$ & Disease & Media & Remarks & Ref. \\
\hline Botrytis cinerea & Grey mold & YNB & $\begin{array}{l}\text { Coagulation and leakage of the cytoplasm of } \\
\text { pathogenic fungus }\end{array}$ & [12] \\
\hline 18 strains of $B$. cinerea & Grey mold & YMB & $\begin{array}{l}\text { P. membranifaciens had an inhibitory effect via } \\
\text { killer toxin activity }\end{array}$ & [13] \\
\hline Penicillium roqueforti & - & MEB & $\begin{array}{l}\text { Pichia strains strongly inhibited } P \text {. roqueforti in } \\
\text { the mini-silos }\end{array}$ & [33] \\
\hline Colletotrichum acutatum & $\begin{array}{l}\text { Anthracnose } \\
\text { rot }\end{array}$ & NYDB & $\begin{array}{l}\text { Improved biocontrol and increased enzyme } \\
\text { activity in the presence of } \mathrm{CaCl}_{2} \text {, inhibited spore } \\
\text { germination of fungus }\end{array}$ & [17] \\
\hline Colletotrichum acutatum & $\begin{array}{l}\text { Anthracnose } \\
\text { rot }\end{array}$ & NYDB & $\begin{array}{l}\text { Methyl jasmonate remarkably improved control } \\
\text { and increased the population of antagonist yeast } \\
\text { against pathogen fungus }\end{array}$ & {$[18]$} \\
\hline $\begin{array}{l}\text { Brettanomyces } \\
\text { bruxellensis }\end{array}$ & - & YMB & $\begin{array}{l}\text { Biocontrol activity of PMKT2 in winemaking } \\
\text { condition, preventing contamination }\end{array}$ & {$[34]$} \\
\hline Penicillium expansum & Blue mold & NYDB & $\begin{array}{l}\text { Ammonium molybdate increased the growth of } P \text {. } \\
\text { membranifaciens and improved the efficacy } \\
\text { control of disease }\end{array}$ & [19] \\
\hline Penicillium expansum & Blue mold & NYDB & $\begin{array}{l}\text { Hydrolytic enzymes synergistic effect with benzo- } \\
\text { thiadiazole-7-carbothioic acid S-methyl ester } \\
\text { (BTH) }\end{array}$ & {$[20]$} \\
\hline Penicillium expansum & Blue mold & NYDB & $\begin{array}{l}\text { Lentinula edodes improved the efficacy, induced } \\
\text { higher phenolic accumulation, and up-regulation of } \\
\text { enzyme activity }\end{array}$ & {$[35]$} \\
\hline Monilinia fructicola & Brown rot & NYDB & Controlled $76 \%$ of disease in vivo & {$[21]$} \\
\hline $\begin{array}{l}\text { Colletotrichum } \\
\text { gloeosporioides }\end{array}$ & 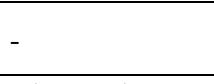 & PDB & $\begin{array}{l}\text { Reduced fungal growth, competition for limited } \\
\text { resources and antibiosis }\end{array}$ & [36] \\
\hline $\begin{array}{l}\text { Penicillium expansum } \\
\text { Botrytis cinerea }\end{array}$ & $\begin{array}{l}\text { Blue and grey } \\
\text { mold }\end{array}$ & Pear juice & $\begin{array}{l}\text { Adding several amino acids and/or } \mathrm{CaCl}_{2} \text { resulted } \\
\text { in improved antagonistic activity }\end{array}$ & {$[37]$} \\
\hline $\begin{array}{lll}\text { Fusarium } & \text { spp } & \text { and } \\
\text { Verticillium } & \text { spp }\end{array}$ & Coffee rust & Coffee & Slowing down the progress of the rust disease & {$[38]$} \\
\hline $\begin{array}{l}\text { Fusarium verticillioides } \\
\text { Fusarium proliferatum }\end{array}$ & - & $\begin{array}{l}\text { Sweet corn } \\
\text { seed }\end{array}$ & $\begin{array}{l}\text { Reduced fumonisin production by } F \text {. verticillioides } \\
\text { by } 73 \% \text { and reduced fumonisins by } F \text {. proliferatum } \\
\text { by } 56 \%\end{array}$ & [39] \\
\hline Pinicillium digitatum & Green mold & \multirow{3}{*}{$\begin{array}{l}\text { Bagasse } \\
\text { hydrolysate }\end{array}$} & \multirow{3}{*}{$\begin{array}{l}\text { Production of bio-fungicide inhibited the growth } \\
\text { and destroyed hyphae of pathogen fungi, and at } \\
3782 \mathrm{mg} / \mathrm{l} \text { concentration could annihilate the } \\
\text { pathogenic fungi }\end{array}$} & \multirow{3}{*}{$\begin{array}{l}\text { This } \\
\text { study }\end{array}$} \\
\hline Phythophtora capsici & White mold & & & \\
\hline Aspergillus niger & Black mold & & & \\
\hline
\end{tabular}

\section{Conclusions}

In this study, the production of bio-fungicide from sugarcane bagasse as a cost-effective carbon source using the yeast $P$. membranifaciens was investigated. The activity and toxicity of the produced bio-fungicide on three pathogenic fungi, $P$. digitatum, $P$. capsici, and A. niger known as fruit rotting pathogenic fungi, were demonstrated. The results of this study were promising in the sense that lignocellulosic wastes can be used as a low-cost carbon source for the production of bio-fungicide for preserving agricultural crops and products against postharvest pathogenic fungi.

\section{Funding}

This work was supported by Biotechnology Research Laboratory, the Babol Noshirvani University of Technology through MSc grant no. BNUT/935150006/97.

\section{Acknowledgments}

The author also would like to thank the research and development group of Partonar Company for their technical assistance in pathogenic fungi studies. 


\section{Conflicts of Interest}

\section{The authors declare no conflict of interest.}

\section{References}

1. Yu, L.; Qiao, N.; Zhao, J.; Zhang, H.; Tian, F.; Zhai, Q.; Chen, W. Postharvest control of Penicillium expansum in fruits: A review. Food Biosci. 2020, 36, https://doi.org/10.1016/j.fbio.2020.100633.

2. Lutz, M.C.; Lopes, C.A.; Sosa, M.C.; Sangorrin, M.P. Semi-commercial testing of native yeasts selected from north patagonia argentina for the biocontrol of pear post-harvest decays. Biol. Control 2020, 150, https://doi.org/10.1016/j.biocontrol.2020.104246.

3. Zhao, S.; Guo, Y.; Wang, Q.; Luo, H.; He, C.; An, B. Expression of flagellin at yeast surface increases biocontrol efficiency of yeast cells against post-harvest disease of tomato caused by Botrytis cinerea. Postharvest Biol. Technol. 2020, 162, https://doi.org/10.1016/j.postharvbio.2019.111112.

4. Spadaro, D.; Garibaldi, A.; Gullino, M.L. Control of Penicillium expansum and Botrytis cinerea on apple combining a biocontrol agent with hot water dipping and acibenzolar-S-methyl, baking soda, or ethanol application. Postharvest Biol. Technol. https://doi.org/10.1016/j.postharvbio.2004.02.002

5. Dhanasekaran, D.; Thangaraj R. Microbial secondary metabolites are an alternative approaches against insect vector to prevent zoonotic diseases. Asian Pac. J. Trop. Dis. 2014, 4, 253-261, https://doi.org/10.1016/S2222-1808(14)60569-7.

6. Villalba, M.L.; Mazzucco, M.B.; Lopes, C.A.; Ganga, M.A.; Sangorrin, M.P. Purification and characterization of Saccharomyces eubayanus killer toxin: Biocontrol effectiveness against wine spoilage yeasts. Food Microbiol. 2020, 331, https://doi.org/10.1016/j.ijfoodmicro.2020.108714.

7. Freimoser, F.M.; Ruede-Mejia, M.P.; Tilocca, B.; Migheli, Q. Biocontrol yeasts: mechanisms and applications. World J. Microbiol. Biotechnol. 2019, 35, https://doi.org/10.1007/s11274-019-2728-4.

8. Lasa, R.; Navarro-de-la-Fuente, L.; Gschaedler-Mathis, A.C.; Kirchmayr, M.R.; Williams, T. Yeast species, strains, and growth media mediate attraction of Drosophila suzukii (Diptera: Drosophilidae). Insects 2019, 10, https://doi.org/10.3390/insects10080228.

9. Marquina, D.; Peres, C.; Caldas, F.V.; Marques, J.F.; Peinado, J.M.; Spencer-Martins, I. Characterization of the yeast population in olive brines. Lett. Appl. Microbiol. 1992, 14, 279-283, https://doi.org/10.1111/j.1472765X.1992.tb00705.x.

10. Mannazzu, I.; Domizio, P.; Carboni, G.; Zara, S.; Zara, G.; Comitini, F.; Budroni, M.; Ciani, M. Yeast killer toxins: from ecological significance to application. Crit. Rev. Biotechnol. 2019, 39, 603-617, https://doi.org/10.1080/07388551.2019.1601679.

11. Santos, A.; Alonso, A.; Belda, I.; Marquina, D. Cell cycle arrest and apoptosis, two alternative mechanisms for PMKT2 killer activity. Fungal Genet. Biol. 2013, 50, 44-54, https://doi.org/10.1016/j.fgb.2012.10.006.

12. Masih, E.I.; Slezack-Deschaumes, S.; Marmaras, I.; Ait Barka, E.; Vernet, G.; Charpentier, C.; Adholeya, A.; Paul, B. Characterisation of the yeast Pichia membranifaciens and its possible use in the biological control of Botrytis cinerea, causing the grey mould disease of grapevine. FEMS Microbiol. Lett. 2001, 202, 227-232, http://dx.doi.org/10.1016/S0378-1097(01)00323-8.

13. Santos, A.; Sánchez, A.; Marquina, D. Yeasts as biological agents to control Botrytis cinerea. Microbiol. Res. 2004, 159, 331-338, http://dx.doi.org/10.1016/j.micres.2004.07.001

14. Wang, X.; Yuan, Z.; Shi, Y.; Cai, F.; Zhao, J.; Wang, J.; Wang, Y. Bacillus amyloliquefaciens HG01 induces resistance in loquats against anthracnose rot caused by Colletotrichum acutatum. Postharvest Biol. Technol. 2020, 160, https://doi.org/10.1016/j.postharvbio.2019.111034.

15. Into, P.; Khunnamwong, P.; Jindamoragot, S.; Am-in, S.; Intanoo, W.; Limtong, S. Yeast associated with rice phylloplane and their contribution to control of rice sheath blight disease. Microorganisms 2020, 8, https://doi.org/10.3390/microorganisms8030362.

16. Godana, E.A.; Yang, Q.; Wang, K.; Zhang, H.; Zhang, X.; Zhao, L.; Abdelhai, M.H.; Legrand, N.N.G. Biocontrol activity of Pichia anomala supplemented with chitosan against Penicillium expansum in post-harvest grapes and its possible inhibition mechanism. LWT-Food Sci. Technol. 2020, 124, https://doi.org/10.1016/j.lwt.2020.109188.

17. Cao, S.; Zheng, Y.; Tang, S.; Wang, K. Improved control of anthracnose rot in loquat fruit by a combination treatment of Pichia membranifaciens with $\mathrm{CaCl}_{2}$. Int. J. Food Microbiol. 2008, 126, 216-220, http://dx.doi.org/10.1016/j.ijfoodmicro.2008.05.026.

18. Cao, S.; Zheng, Y.; Wang, K.; Tang, S.; Rui, H. Effect of yeast antagonist in combination with methyl jasmonate treatment on post-harvest anthracnose rot of loquat fruit. Biol. Control 2009, 50, 73-77, https://doi.org/10.1016/j.biocontrol.2009.02.003.

19. Cao, S.; Yuan, Y.; Hu, Z.; Zheng, Y. Combination of Pichia membranifaciens and ammonium molybdate for controlling blue mould caused by Penicillium expansum in peach fruit. Int. J. Food Microbiol. 2010, 141, 173-176, http://dx.doi.org/10.1016/j.ijfoodmicro.2010.05.009 
20. Cao, S.; Yuan, Y.; Hu, Z.; Zheng, Y. The effects of the combination of Pichia membranefaciens and BTH on controlling of blue mould decay caused by Penicillium expansum in peach fruit. Food Chem. 2011, 124, 991-996, http://dx.doi.org/10.1016/j.foodchem.2010.07.041.

21. Zhang, J.; Xie, J.; Zhou, Y.; Deng, L.; Yao, S.; Zeng, K. Inhibitory effect of Pichia membranaefaciens and Kloeckera apiculata against Monilinia fructicola and their biocontrol ability of brown rot in post-harvest plum. Biol. Control 2017, 114, 51-58, http://dx.doi.org/10.1016/j.biocontrol.2017.07.013.

22. Gonda, M.; Garmendia, G.; Rufo, C.; León Peláez, Á.; Wisniewski, M.; Droby, S.; Vero, S. Biocontrol of Aspergillus flavus in Ensiled Sorghum by Water Kefir Microorganisms. Microorganisms 2019, 7 , https://doi.org/10.3390/microorganisms7080253.

23. Zhang, H.; Deng, L.; Yao, S.; Ming, J.; Zeng, K. Optimization of a vacuum-drying protectants for the biocontrol agent Pichia membranifaciens and its influence on viability and efficacy. Biol. Control 2020, 142, https://doi.org/10.1016/j.biocontrol.2019.104155.

24. Usall, J.; Torres, R.; Teixidó, N. Biological control of post-harvest diseases on fruit: a suitable alternative? Curr. Opin. Food Sci. 2016, 11, 51-55, https://doi.org/10.1016/j.cofs.2016.09.002.

25. Konsue, W.; Dethoup, T.; Limtong, S. Biological control of fruit rot and anthracnose of post-harvest mango by antagonistic yeasts from economic crops leaves. Microorganisms 2020, 8, https://doi.org/10.3390/microorganisms8030317.

26. Rajagopalan, G.; Krishnan, C. $\alpha$-Amylase production from catabolite derepressed Bacillus subtilis KCC103 utilizing sugarcane bagasse hydrolysate. Bioresour. Technol. 2008, 99, 3044-3050, https://doi.org/10.1016/j.biortech.2007.06.001.

27. Zhang, W.-H.; Wu, J.; Weng, L.; Zhang, H.; Zhang, J.; Wu, A. An improved phenol-sulfuric acid method for the determination of carbohydrates in the presence of persulfate. Carbohydr. Polym. 2020, 227, https://doi.org/10.1016/j.carbpol.2019.115332.

28. Jain, A.; Jain, R.; Jain, S. Quantitative analysis of reducing sugars by 3, 5-Dinitrosalicylic acid (DNSA Method), Basic Techniques in Biochemistry. In: Microbiology and Molecular Biology. Springer Protocols Handbooks. Humana, New York, NY. 2020; pp. 181-183, https://doi.org/10.1007/978-1-4939-9861-6.

29. Kielkopf, C.L.; Bauer, W.; Urbatsch, I.L. Bradford assay for determining protein concentration. Cold Spring Harb. Protoc. 2020, 2020, https://doi.org/10.1101/pdb.prot102269.

30. Jiang, L. Comparison of disk diffusion, agar dilution, and broth microdiultion for antimicrobial susceptibility testing of five chitosans. LSU Master's Theses, Louisiana State University and Agricultural and Mechanical College, 2011.

31. Chen, Y.-J.; Wang, C.-J.; Hou, W.-Q.; Wang, X.-S.; Gali, B.-G.; Yang, S.-Q.; Zhao, Y.-F.; Wu, Y.-G. Effects of antibacterial compounds produced by Saccharomyces cerevisiae in Koumiss on pathogenic Escherichia coli $O s$ and its cell surface characteristics. J. Integr. Agric. 2017, 16, 742-748, https://doi.org/10.1016/S2095-3119(16)61516-2.

32. Krishnan, R.; Arumugam, V.; Vasaviah, S.K. The MIC and MBC of silver nanoparticles against Enterococcus faecalis-a facultative anaerobe. J. Nanomed. Nanotechnol. 2015, 6, http://dx.doi.org/10.4172/2157-7439.1000285.

33. Ädel Druvefors, U.; Schnürer, J. Mold-inhibitory activity of different yeast species during airtight storage of wheat grain. FEMS Yeast Res. 2005, 5, 373-378, https://doi.org/10.1016/j.femsyr.2004.10.006.

34. Santos, A.; San Mauro, M.; Bravo, E.; Marquina, D. PMKT2, a new killer toxin from Pichia membranifaciens, and its promising biotechnological properties for control of the spoilage yeast Brettanomyces bruxellensis. Microbiology 2009, 155, 624-634, https://doi.org/10.1099/mic.0.023663-0.

35. Wang, J.; Wang, H.-Y.; Xia, X.-M.; Li, P.-P.; Wang, K.-Y. Synergistic effect of Lentinula edodes and Pichia membranefaciens on inhibition of Penicillium expansum infections. Postharvest Biol. Technol. 2013, 81, 712, https://doi.org/10.1016/j.postharvbio.2013.02.002.

36. Pesce, V.M.; Nally, M.C.; Carrizo, G.P.; Rojo, C.; Pérez, B.A.; Toro, M.E.; de Figueroa, L.I.C.; Vazquez, F. Antifungal activity of native yeasts from different microenvironments against Colletotrichum gloeosporioides on ripe olive fruits. Biol. Control 2018, 120, 43-51, https://doi.org/10.1016/j.biocontrol.2017.03.005.

37. Gramisci, B.R.; Lutz, M.C.; Lopes, C.A.; Sangorrín, M.P. Enhancing the efficacy of yeast biocontrol agents against post-harvest pathogens through nutrient profiling and the use of other additives. Biol. Control 2018, 121, 151-158, https://doi.org/10.1016/j.biocontrol.2018.03.001.

38. Melchor, R.L.A.; Rosales, V.G.; Pérez, M.C.G.; Fernández, S.P.; Álvarez, G.O.; Mastache, J.M.N. Effectiveness of carboxylic acids from Pichia membranifaciens against coffee rust. Ciênc. Agrotecnol. 2018, 42, 42-50, https://doi.org/10.1590/1413-70542018421018817.

39. Ridout, M.E.; Godfrey, B.; Newcombe, G. Effects of antagonists on mycotoxins of seedborne Fusarium spp. in sweet corn. Toxins 2019, 11, https://doi.org/10.3390/toxins11080438. 